\section{Evaluating the Immune Response and Antioxidant Potential in Four Broiler Strains under Chronic High Ambient Temperature}

\author{
Zia-ur-Rehaman ${ }^{1}$, Naila Chand ${ }^{1}$, Sarzamin $\operatorname{Khan}^{1}$ and Rifat Ullah Khan ${ }^{2, *}$ \\ ${ }^{1}$ Department of Poultry Science, Faculty of Animal Husbandry and Veterinary Sciences, \\ The University of Agriculture, Peshawar, Pakistan \\ ${ }^{2}$ Department of Animal Health, Faculty of Animal Husbandry and Veterinary Sciences, \\ The University of Agriculture, Peshawar, Pakistan
}
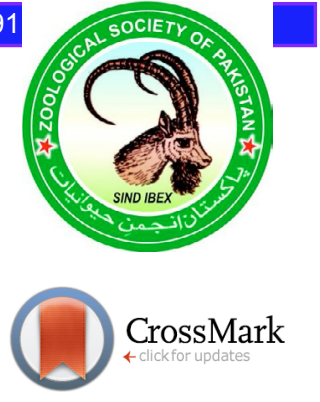

\begin{abstract}
A B S T R A C T
The present study was carried out to evaluate the effects of thermoneutral (TN) and high ambient temperature (HAT) on immune response and oxidative status of four broiler strains. Day old broiler chicks ( $\mathrm{n}=242$ ) of four different commercial strains (Ross, Hubbard, Cobb and Arber Acer) were placed in brooding room in first two weeks and then chicks were divided into two groups: TN and HAT zones. Chicks in TN group were housed at constant room temperature, while chicks in HAT zone were kept at high ambient temperature. Chicks in each group were further divided into four sub groups. Each sub group was further subdivided into four replicates having ten chicks per replicate. Blood was collected on weekly basis from day 21 to 42 . Mean serum antibody titer against Newcastle disease (ND) and serum paraoxonase $(\mathrm{PON} 1)$ were significantly higher $(\mathrm{P}<0.05)$ in $\mathrm{TN}$ zone, while serum malondialdehyde (MDA) was significantly $(\mathrm{P}<0.05)$ higher in HAT zone. No significant differences were recorded in serum antibody titer against ND, PON1 and MDA among different broiler strains in TN zone, while in HAT zone, Ross and Arber Acer showed significantly $(\mathrm{P}<0.05)$ higher serum antibody titer against ND. In HAT zone, significantly $(\mathrm{P}<0.05)$ lower serum MDA was found in Ross and Arber Acer. Based on these results, it was concluded that chronic high ambient temperature has negative effect on broiler immune and oxidative status. Ross and Arber Acer strains were more tolerant to summer high ambient temperature of tropical areas than Cobb and Hubbard.
\end{abstract}

\begin{tabular}{l} 
Article Information \\
Received 22 April 2017 \\
Revised 16 June 2017 \\
Accepted 07 July 2017 \\
Available online 02 November 2017 \\
Authors' Contribution \\
\hline ZR conducted the study. NC and SK \\
designed the study. RUK analysed \\
sample and edited the paper. \\
Key words \\
Broiler strains, Antibody titer, \\
Paraoxonase, Malondialdehyde.
\end{tabular}

\section{INTRODUCTION}

$\mathrm{I}^{\mathrm{n}}$ $n$ tropical and subtropical countries, heat stress of summer seasons is a major stressor in poultry industry that produces a wide range of physiological and behavioral responses (Khan et al., 2011). Heat stress induced losses are the major concerns of the hot regions of the world. Heat stress reduces feed intake, weight gains and increases mortality in poultry industry (Chand et al., 2016). Stressful condition stimulates the production of reactive oxygen species (ROS) excessively, causing oxidative damage to protein, lipid and nucleic acid (Khan et al., 2011). Physiological and biochemical changes associated with high temperature accelerate ROS formation (Chand et al., 2016; Naz et al., 2016). High concentration of ROS causes oxidative injury and severe cellular damage (Khan et al., 2011; Alzawqari et al., 2016; Alhidary et al., 2016). Different antioxidant enzymes such superoxide dismutase (SOD), glutathione

\footnotetext{
* Corresponding author: rifatullahkhhan@gmail.com 0030-9923/2017/0006-2087 \$ 9.00/0

Copyright 2017 Zoological Society of Pakistan
}

peroxidase (GSH-Px) and paraoxonase (PON1) are very important in scavenging free radicals and their metabolites to maintain normal cellular physiology (Khan et al., 2014a; Shah et al., 2016). Heat stress causes oxidative stress and increases malondialdehyde (MDA) and decreases PON1 activities (Chand et al., 2016).

Over the last several decades, genetic selection for optimum performance in term of faster growth, better feed efficiency and higher disease resistance are considered very important for commercial poultry production (Khan, 2011; Khan et al., 2016; Abudabos et al., 2017). Birds usually adopt themselves to the changing environmental conditions by redistributing the body reservoirs of protein and energy which may negatively affect the growth and reproduction. Heat stress stimulates the catecholamine to prepare birds for fight and flight response during heat stress, which releases the glucose. During the fight against the heat stress, if the bird is not able to cope with the heat, the exhaustive phase leads to disturbance in the homeostatic mechanisms resulting in the death of the birds (Khan et al., 2012a). Determination of immune status is a common indicator in birds to find the health status (Khan 
et al., 2014b) especially during the stressful condition. The interaction between genotype and environment exerts a major effect on the suitability of a strain of broiler in a particular area of the world (Khan et al., 2012a). High environmental temperature affects the immune system of broiler causing a reduction in antibody production (Chand et al. 2014).

The objective of the present study was to investigate the immune response and antioxidant status of four commercial broiler strains (Ross, Hubbard, Cobb and Arber Acres) reared in thermo neutral (TN) and high ambient temperature (HAT).

Table I.- Ingredient composition of starter and finisher diets.

\begin{tabular}{lll}
\hline Ingredient name (\%) & Starter & Finisher \\
\hline Corn & 58 & 60 \\
Poultry byproduct meal & 4 & 4 \\
Rice broken & 0 & 4 \\
Canola meal & 8 & 10 \\
Sunflower meal & 5 & 3 \\
Corn gluten & 2 & 2 \\
Rapeseed meal & 2 & 0 \\
Soybean meal & 15 & 13 \\
Soybean oil & 0 & 1 \\
Guar meal & 3 & 0 \\
Bone meal & 0.5 & 0.5 \\
Dicalcium phosphate & 0.5 & 0.8 \\
Sodium chloride & 0.2 & 0.2 \\
Lysine HCl & 0.2 & 0.2 \\
Lysine Sulphate & 0.42 & 0.3 \\
Vitamin mineral pre mix & 0.3 & .5 \\
L-Threonine & 0.05 & 0.05 \\
DL Methonoine & 0.12 & 0.1 \\
Lime stone & 0.8 & 0.8 \\
\hline
\end{tabular}

\section{MATERIALS AND METHODS}

\section{Experimental design and birds' husbandry}

The experiment was conducted in a completely randomized design with two factors (temperature zones) and four different broiler strains (Ross, Hubbard, Cobb and Arber Acres). A total of two hundred and forty day old broiler chicks of four commercial broiler strains of the same age and size were used in the study. In the first two weeks, chicks were placed in a brooding room and then divided into two groups: TN and HAT zones. Chicks in TN zone were housed at constant room temperature $\left(25^{\circ} \mathrm{C} \pm\right.$ $2 \mathrm{C}^{\circ}$ and $\mathrm{RH} 65 \pm 5 \%$ ), while chicks in HAT zone were kept at high ambient temperature. Both the groups were kept in two different rooms which were identical in term of size, construction materials and equipments. The temperature and humidity were recorded after every four hours in the centre of the house and minimum and maximum values of each day was averaged per week. Chicks in each group were further divided into four sub groups. Each sub group was further subdivided into four replicates having ten chicks per replicate. Feed and water were provided ad libitum. During the first 21 days, chicks were provided with starter ration containing $22 \%$ crude protein (CP) and $3000 \mathrm{kcal} / \mathrm{kg}$ metabolizable energy (ME). During the last three weeks, chicks were provided with finisher ration containing $20 \% \mathrm{CP}$ and $3200 \mathrm{Kcal} / \mathrm{kg} \mathrm{ME}$. The feed composition and proximate analysis are given in Tables I and II, respectively.

All birds of four strains were vaccinated with Newcastle vaccine specified schedule.

Table II.- Chemical composition (nutritive values) of starter and finisher ration.

\begin{tabular}{lll}
\hline Ingredient name & Starter & Finisher \\
\hline Crude protein (\%) & 22.00 & 20.00 \\
Crude fiber (\%) & 5.27 & 4.58 \\
Ether extract (\%) & 4.28 & 4.17 \\
Calcium (\%) & 0.88 & 0.84 \\
Phosphorus (\%) & 0.44 & 0.42 \\
Lysine (\%) & 1.35 & 1.21 \\
Methonine and Cysteine (\%) & 0.94 & 0.84 \\
Threonine (\%) & 0.87 & 0.80 \\
ME/Kcal/kg & 3000 & 3200 \\
\hline
\end{tabular}

Temperature and humidity data

House temperature and humidity were recorded after every four hours in the centre of the house at an interval of four hours (08:00 am, 12:00 pm, 4:00 pm, 8:00 pm, 12:00 am, and 4:00 am) (Table III).

\section{Collection of serum and analysis}

Blood samples were collected on day 21, 28, 35 and 42 from randomly selected birds (two birds per replicate) for biochemical analysis. Blood was collected from the wing vein with the help of a disposable syringe. Blood samples were centrifuged at 2,000 rpm for $10 \mathrm{~min}$ for serum separation. Antibody titer of ND was determined through ELISA test. The PON1 activity was determined with $2 \mathrm{mmol} / \mathrm{L}$ of paraoxon (Sigma Chemical Co., London, UK) and measured spectrophotometrically. The MDA level was determined by the method described by Chand et al. (2016). 
Table III.- Mean temperature and relative humidity during the experimental period.

\begin{tabular}{lcc}
\hline Hour & Ambient temp. (C) & Relative humidity (\%) \\
\hline $08: 00 \mathrm{am}$ & $31.66 \pm 0.94$ & $51.65 \pm 0.32$ \\
$12: 00 \mathrm{pm}$ & $36.43 \pm 0.12$ & $52.29 \pm 0.91$ \\
$04: 00 \mathrm{pm}$ & $33.25 \pm 0.45$ & $65.32 \pm 0.47$ \\
$8: 00 \mathrm{pm}$ & $31.62 \pm 0.82$ & $64.43 \pm 0.78$ \\
$12: 00 \mathrm{am}$ & $29.85 \pm 0.91$ & $60.67 \pm 0.82$ \\
$04: 00 \mathrm{am}$ & $28.87 \pm 0.43$ & $55.22 \pm 0.11$ \\
\hline
\end{tabular}

Statistical analysis

Data was statistically analyzed with one way analysis of variance using statistical package SAS (SAS Institute, 1992). Least significant test was used to compare the differences among treatment means to find the significant difference. $\mathrm{P}$ value less than 0.05 was statistically considered significant.

\section{RESULTS}

Mean serum antibody titer against ND of four different broiler strains reared in TN and HAT zone is shown in Table IV. No significant difference was found in mean serum antibody titer of four different broiler strains against ND in TN zone, while in HAT zone, significantly higher mean serum antibody titer against ND was found in Ross and Arbor Acres followed by Cobb and Hubbard at all recorded stages.

Mean serum MDA of four different broiler strains reared in TN and HAT zone are presented in Table V. Significantly $(\mathrm{P}<0.05)$ lower serum MDA was recorded in all broiler strains in TN zone at all recorded stages. In HAT zone, significantly lower $(\mathrm{P}<0.05)$ serum MDA was recorded in Ross and Arbor Acres at all recorded stages except day 21. On day 21, no significant difference was recorded in mean serum MDA level of different broiler strains in HAT zone.

Table IV.- Antibody titer against Newcastle disease (ND) of different broiler strains reared under thermo neutral (TN) and high ambient temperature (HAT) zones.

\begin{tabular}{llllll}
\hline Zone & Strain & Day 21 & Day 28 & Day 35 & Day 42 \\
\hline TN zone & Ross & $1647.8 \pm 4.21^{\mathrm{a}}$ & $1561.5 \pm 6.23^{\mathrm{a}}$ & $1406 \pm 4.76^{\mathrm{a}}$ & $1253.3 \pm 3.35^{\mathrm{a}}$ \\
& Hubbard & $1658.0 \pm 8.20^{\mathrm{a}}$ & $1557.5 \pm 12.3^{\mathrm{a}}$ & $1433.8 \pm 8.11^{\mathrm{a}}$ & $1255.8 \pm 11.75^{\mathrm{a}}$ \\
& Cobb & $1647.8 \pm 3.90^{\mathrm{a}}$ & $1552 \pm 10.15^{\mathrm{a}}$ & $1409 \pm 7.59^{\mathrm{a}}$ & $1266.3 \pm 7.50^{\mathrm{a}}$ \\
& Arbor Acres & $1645.5 \pm 4.34^{\mathrm{a}}$ & $1532.5 \pm 5.2^{\mathrm{a}}$ & $1407.2 \pm 3.81^{\mathrm{a}}$ & $1253.3 \pm 5.45^{\mathrm{a}}$ \\
\multirow{2}{*}{ HAT zone } & Ross & $1594.5 \pm 6.23^{\mathrm{b}}$ & $1480 \pm 4.56^{\mathrm{b}}$ & $1348 \pm 7.78^{\mathrm{bc}}$ & $1207.5 \pm 3.77^{\mathrm{b}}$ \\
& Hubbard & $1553.8 \pm 8.25^{\mathrm{c}}$ & $1432 \pm 10.68^{\mathrm{c}}$ & $1327.5 \pm 3.22^{\mathrm{bc}}$ & $1172.3 \pm 4.20^{\mathrm{c}}$ \\
& Cobb & $1544.5 \pm 11.44^{\mathrm{c}}$ & $1440 \pm 15.54^{\mathrm{c}}$ & $1320 \pm 7.07^{\mathrm{c}}$ & $1169 \pm 17.96^{\mathrm{c}}$ \\
& Arbor Acres & $1586.8 \pm 4.26^{\mathrm{b}}$ & $1474 \pm 1.29^{\mathrm{b}}$ & $1353.8 \pm 5.89^{\mathrm{b}}$ & $1215 \pm 10.40^{\mathrm{b}}$ \\
\hline
\end{tabular}

Means in the same column with different superscripts are significantly different $(\mathrm{P}<0.05)$.

Table V.- Serum malondialdehyde (MDA) (nmol/ml) $($ Mean \pm SD) of different broiler strains reared under thermo neutral and high ambient temperature.

\begin{tabular}{llllll}
\hline Zone & Strain & Day 21 & Day 28 & Day 35 & Day 42 \\
\hline TN zone & Ross & $6.90 \pm 0.14^{\mathrm{b}}$ & $9.08 \pm 0.06^{\mathrm{c}}$ & $9.41 \pm 0.23^{\mathrm{c}}$ & $11.69 \pm 0.09^{\mathrm{c}}$ \\
& Hubbard & $6.76 \pm 0.13^{\mathrm{b}}$ & $8.94 \pm 0.07^{\mathrm{c}}$ & $8.93 \pm 0.28^{\mathrm{c}}$ & $11.30 \pm 0.21^{\mathrm{c}}$ \\
& Cobb & $6.45 \pm 0.28^{\mathrm{b}}$ & $8.87 \pm 0.05^{\mathrm{c}}$ & $8.8 \pm 0.32^{\mathrm{c}}$ & $11.37 \pm 0.17^{\mathrm{c}}$ \\
& Arbor acres & $6.60 \pm 0.21^{\mathrm{b}}$ & $8.98 \pm 0.031^{\mathrm{c}}$ & $9.14 \pm 0.28^{\mathrm{c}}$ & $11.72 \pm 0.20^{\mathrm{c}}$ \\
HAT zone & Ross & $8.45 \pm 0.17^{\mathrm{a}}$ & $10.26 \pm 0.08^{\mathrm{b}}$ & $10.46 \pm 0.24^{\mathrm{b}}$ & $13.22 \pm 0.28^{\mathrm{b}}$ \\
& Hubbard & $9.18 \pm 0.14^{\mathrm{a}}$ & $11.65 \pm 0.12^{\mathrm{a}}$ & $11.8 \pm 0.48^{\mathrm{a}}$ & $14.34 \pm 0.07^{\mathrm{a}}$ \\
& Cobb & $9.22 \pm 0.26^{\mathrm{a}}$ & $11.79 \pm 0.12^{\mathrm{a}}$ & $11.88 \pm 0.41^{\mathrm{a}}$ & $14.32 \pm 0.41^{\mathrm{a}}$ \\
& Arbor Acres & $8.47 \pm 0.18^{\mathrm{a}}$ & $10.15 \pm 0.08^{\mathrm{b}}$ & $10.37 \pm 0.19^{\mathrm{b}}$ & $13.47 \pm 0.22^{\mathrm{b}}$ \\
\hline
\end{tabular}

Means in the same column with different superscripts are significantly different $(\mathrm{P}<0.05)$. 
Table VI.- Serum paraoxonase (U/L) (Mean \pm SD) of different broiler strains reared in thermo neutral and high ambient temperature zones.

\begin{tabular}{llllll}
\hline Zone & Strain & Day 21 & Day 28 & Day 35 & Day 42 \\
\hline TN zone & Ross & $13.36 \pm 0.20^{\mathrm{a}}$ & $12.75 \pm 0.035^{\mathrm{a}}$ & $12.07 \pm 0.097^{\mathrm{a}}$ & $11.54 \pm 0.281^{\mathrm{a}}$ \\
& Hubbard & $13.64 \pm 0.153^{\mathrm{a}}$ & $12.82 \pm 0.26^{\mathrm{a}}$ & $12.26 \pm 0.090^{\mathrm{a}}$ & $11.89 \pm 0.167^{\mathrm{a}}$ \\
& Cobb & $13.48 \pm 0.20^{\mathrm{a}}$ & $13.01 \pm 0.13^{\mathrm{a}}$ & $12.05 \pm 0.10^{\mathrm{a}}$ & $11.79 \pm 0.068^{\mathrm{a}}$ \\
& Arber Acres & $13.35 \pm 0.269^{\mathrm{a}}$ & $12.77 \pm 0.076^{\mathrm{a}}$ & $11.98 \pm 0.134^{\mathrm{a}}$ & $11.57 \pm 0.086^{\mathrm{a}}$ \\
HAT zone & Ross & $12.30 \pm 0.20^{\mathrm{b}}$ & $12.19 \pm 0.29^{\mathrm{b}}$ & $11.41 \pm 0.099^{\mathrm{b}}$ & $10.86 \pm 0.087^{\mathrm{b}}$ \\
& Hubbard & $11.72 \pm 0.17^{\mathrm{c}}$ & $11.52 \pm 0.11^{\mathrm{c}}$ & $10.76 \pm 0.092^{\mathrm{d}}$ & $10.82 \pm 0.118^{\mathrm{b}}$ \\
& Cobb & $11.42 \pm 0.075^{\mathrm{c}}$ & $11.32 \pm 0.060^{\mathrm{c}}$ & $10.94 \pm 0.092^{\mathrm{cd}}$ & $10.50 \pm 0.106^{\mathrm{b}}$ \\
& Arber Acres & $12.58 \pm 0.134^{\mathrm{b}}$ & $12.16 \pm 0.080^{\mathrm{b}}$ & $11.20 \pm 0.076^{\mathrm{bc}}$ & $10.82 \pm 0.114^{\mathrm{b}}$ \\
\hline
\end{tabular}

Means in the same column with different superscripts are significantly different at $\alpha=0.05$.

Mean serum PON1 activity of four different broiler strains reared in TN zone and HAT zone are presented in Table VI. Significantly $(\mathrm{P}<0.05)$ higher serum PON1 was recorded in all broiler strains in $\mathrm{TN}$ zone at all recorded stages. In HAT zone, significantly higher $(\mathrm{P}<0.05)$ serum PON1 was recorded in Ross and Arber Acres at all recorded stages except at day 42 . On day 42 , no significant difference was found in mean serum PON1 of all broiler strains.

\section{DISCUSSION}

Heat stress has been known for significant reduction in the growth performance and health status of the birds by reducing the feed intake and production of free radicals. These changes in birds increase the incidence of diseases in heat stressed birds. The results of the present research showed that HAT zone significantly affected mean serum antibody titer against ND. Heat stress damages the immune system of the birds in several ways. Heat stress reduces the formation of immune cells ( $\mathrm{T}$ and $\mathrm{B}$ cells), suppresses the phagocytic activities, lowers the white blood cells (WBCs) and heterophils to lymphocyte ratio (Khan et al., 2012a). In addition, heat stress also impairs the humoral immunity and synthesis of antibodies and increases the inflammatory cytokines.

Heat stress causes oxidative damage and reduces the weight of lymphoid organs (Chand et al., 2014) which may be the probable cause of reduced antibody production against ND disease. It has been reported that stressful condition increases the activity of adrenal gland which increases the production of serum corticosteroids (Ihsanullah et al., 2017) causes suppression of cell proliferation. The decreased antibody titer at high ambient temperature may also be due to the increased inflammatory cytokines and depression of T-helper cells. T-helper cells are responsible for production of antibodies (Khan et al., 2012b). Exposing broiler chicks to high ambient temperature impairs the functions of immune system in hen (Chand et al., 2016), suppresses the defense mechanism of birds and hence decreases antibody production. Several research reports have documented the negative effects of heat stress on the antibody titre in chickens (Khan et al., 2012b; Chand et al., 2014).

Temperature zone significantly affected serum MDA, and PON1 of different broiler strains at all recorded stages. The MDA is a very important byproduct of lipid peroxidation of the lipids contents of the cell membrane and directly responsible for the damage of the cell. High ambient temperature zone significantly increased serum MDA and decreased PON1 of different broiler strains. High ambient temperature increases lipid peroxidation as a result of increased ROS which causes damage to the cellular protein (Chand et al., 2016). Exposure of broiler chicks to high ambient temperature increases lipid peroxidation which is indicated by the increased MDA concentration (Chand et al., 2016). The PON1 is a reliable indicator of antioxidant system and its concentration is generally decreased during the stress condition. This enzyme is also very important in the prevention of the oxidation of the high density lipoprotein. Our findings regarding lower PON1 under high ambient temperature are in agreement to the results of Chand et al. (2016).

\section{CONCLUSION}

The results of the present study revealed that immune response and antioxidant status were significantly affected by HAT and strains of birds. At higher temperature, the measured parameters were most affected in Hubbard 
and Cobb strains. Ross and Arbor Acres showed better resistance to change in the studied physiological parameters during exposure to high ambient temperature. It is concluded from results that Cobb and Hubbard strains exhibited more susceptibility to heat stress, while Ross and Arbor Acres strains were more tolerant to summer high ambient temperature of tropical areas of Peshawar.

\section{Statement of conflict of interest}

Authors have declared no conflict of interest.

\section{REFERENCES}

Abudabos, A.M., Alyemni, A.H., Dafalla, Y.M. and Khan, R.U., 2017. Effect of organic acid blend and Bacillus subtilis alone or in combination on growth traits, blood biochemical and antioxidant status in broiler exposed to Salmonella typhimurium challenge during the starter phase. J. appl. Anim. Res., 45: 538-542. https://doi.org/10.1080/0971211 9.2016.1219665

Alhidary, I.A., Abdelrahman, M.M. and Khan, R.U., 2016. Comparative effects of direct-fed microbial alone or with a traces mineral supplement on the productive performance, blood metabolites and antioxidant status of grazing Awassi lambs. Environ. Sci. Poll. Res., 23: 25218-25223.

Alzawqari, M.H., Al-Baddany, A.A., Al-Baadani, H.H., Alhidary, I.A. and Khan, R.U. Aqil, G.M., and Abdurab, A., 2016. Effect of feeding dried sweet orange (Citrus sinensis) peel and lemon grass (Cymbopogon citratus) leaves on growth performance, carcass traits, serum metabolites and antioxidant status in broiler during the finisher phase. Environ. Sci. Pollut. Res., 23: 17077-17082. https://doi.org/10.1007/s11356-016-6879-7

Chand, N., Khan, A., Khan, S. and Khan, R.U., 2014. Performance traits and immune response of broiler chicks treated with zinc and ascorbic acid supplementation during cyclic heat stress!. Int. J. Biol. Meterol., 58: 2153-2157.

Chand, N., Muhammad, S., Khan, R.U., Alhidary, I.A. and Zia ur Rahman, 2016. Ameliorative effect of synthetic $\gamma$-aminobutyric acid (GABA) on performance traits, antioxidant status and immune response in broiler exposed to cyclic heat stress. Environ. Sci. Pollut. Res., 23: 23930-23935. https:// doi.org/10.1007/s11356-016-7604-2

Ihsanullah, Qureshi, M.S., Suhail, S.M., Akhtar, S. and Khan, R.U., 2017. Postpartum ovarian activities, blood metabolites and milk yield are influenced by changing levels of thermal stress in crossbred dairy cows. Int. J. Biometerol., https://doi.org/10.1007/ s00484-017-1335-z

Khan, R.U., Naz, S., Nikousefat, Z., Tufarelli, V., Javadani, M., Rana, N. and Laudadio, V., 2011. Effect of vitamin E in heat-stressed poultry. World's Poult. Sci. J., 67: 469-478. https://doi.org/10.1017/ S0043933911000511

Khan, R.U., 2011. Antioxidants and poultry semen quality. World's Poult. Sci. J., 67: 297-308. https:// doi.org/10.1017/S0043933911000316

Khan, R.U., Naz, S. and Dhama, K., 2014a. Chromium: pharmacological applications in heat stressed poultry. Int. J. Pharmacol., 10: 213-217. https:// doi.org/10.3923/ijp.2014.213.217

Khan, R.U., Rahman, Z.U., Javed, I. and Muhammad, F., 2014b. Effect of vitamins, protein level and probiotics on immune response of molted male broiler breeders. J. Anim. Physiol. Anim. Nutr., 98: 620-627. https://doi.org/10.1111/jpn.12087

Khan, R.U., Naz, S., Nikousefat, Z., Selvaggi, M., Laudadio, V. and Tufarelli, V., 2012a. Effect of ascorbic acid in heat-stressed poultry. World's Poult. Sci. J., 68: 477-490. https://doi.org/10.1017/ S004393391200058X

Khan, R.U., Rahman, Z.U., Nikousefat, Z., Javdani, M., Tufarelli, V., Dario, C., Selvaggi, M., and Laudadio, V., 2012b. Immuno-modulating effects of vitamin E in broilers. World's Poult. Sci. J., 68: 31-40. https:// doi.org/10.1017/S0043933912000049

Khan, R.U., Chand, N. and Ali, A., 2016. Effect of organic acids on the performance of Japanese quails. Pakistan J. Zool., 48: 1799-1803.

Naz, S., Idris, M., Khalique, M.A., Zia-ur-Rahman, Alhidary, I.A., Abdelrahman, M.M., Khan, R.U., Chand, N., Farooq, U. and Ahmad, S., 2016. The activity and use of zinc in poultry diet. World's Poult. Sci. J., 72: 159-167. https://doi.org/10.1017/ S0043933915002755

SAS Institute, 1992. SAS/STAT user's guide, Version 6. SAS Institute Inc., Cary, NC.

Shah, A.A., Khan, M.S., Khan, S., Ahmad, N., Alhidary, I.A. and Khan, R.U., 2016. Effect of different levels of alpha tocopherol on performance traits, serum antioxidant enzymes, and trace elements in Japanese quail (Coturnix coturnix japonica) under low ambient temperature. Rev. Bras. Zootec., 45: 622-626. https://doi.org/10.1590/S180692902016001000007 